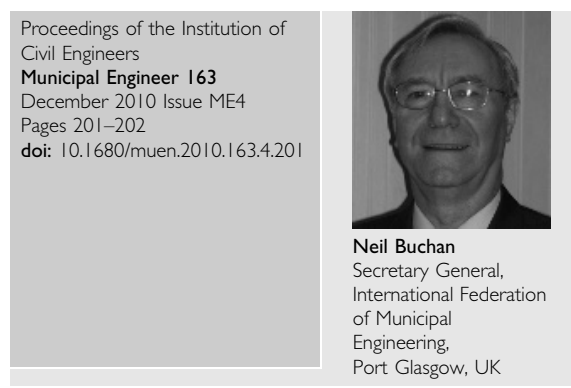

\title{
Editorial: International Federation of Municipal Engineering
}

N. Buchan MBE, BSc, CEng, FICE, FCIHT

A great deal of discussion has taken place recently on the role of the municipal engineer within the Institution of Civil Engineers with several letters and articles on this matter appearing in New Civil Engineer. There can be no doubt that engineering is currently facing enormous challenges in the face of the current worldwide economic turmoil and the field of municipal engineering in particular is likely to be subject to considerable pressures. An inexpensive approach such as maximising the benefits of spreading information on best practice is therefore to be encouraged. This edition of Municipal Engineer is composed of papers delivered at the International Federation of Municipal Engineering (IFME) Triennial Congress in Melbourne in September 2009. The featured papers deal with the wide range of essential aspects of municipal engineering currently being faced by professionals across the globe, many of which have been identified by IFME, and illustrates the benefits in sharing information and work practices which are particularly important in the current economic downturn.

Opening the issue, the briefing paper (Vaskelainen, 2010) gives a short summary of the background of IFME and outlines its mission of connecting all public works professionals, public agencies, organisations, institutions and businesses in order to share knowledge and experience globally. Priorities identified by IFME (i.e. global warming, skills shortage and sustainable management of infrastructure) are dealt with in papers amongst those included in this issue. It is also considered important that IFME expands its present membership from the 16 countries currently involved. Discussions are ongoing with the American association APWA and the recent IFME board meeting took place in Boston allied to their conference. The briefing concludes with an invitation to the next IFME Triennial Congress which will take place in Finland in 2012. It may well be that papers delivered at this event will feature in future themed issues of Municipal Engineer.

The first paper in this issue (Jenkinson, 2010) examines the many ways in which professionals around the world contribute to knowledge sharing and compares and contrasts some of the best known methods of so doing. In the past this has predominantly been achieved through consulting peer-reviewed journals but this long-established process is being severely challenged and overtaken by the use of web-based information. The author highlights the inherent weaknesses of relying exclusively on this approach. Attention is drawn to the fact that the archives of the ICE Proceedings along with other published material has now been made more widely available through the ICE Virtual Library (http://www.icevirtuallibrary.com), providing researchers with access to a wide database of peerreviewed and thus more reliable information on various engineering topics. It concludes by suggesting that the advantages of this approach could be increased by pooling resources on a global basis in order to develop an enhanced tool for sharing engineering practice and knowledge.

The next paper by Glencross-Grant (2010) focuses on the worldwide concern over skills shortages and outlines how this problem is being addressed in rural Australia. Many reasons are suggested for the shortage of professional engineers, particularly in these parts of Australia, which is likely to be intensified by the imminent retrial of a substantial number of experienced engineers from the so-called 'baby boomer' generation along with the lack of promotion of engineering as a career choice by educational authorities. A business plan was developed which took account of research findings and supported the introduction of a degree course specifically focussed on those skills required for dealing with problems of a rural nature. Entry of mature students was also positively encouraged by taking account of previous academic achievements.

In the next paper Hawley et al. (2010) discuss how seven Australian councils approached the problem of how to identify and compare the best practices in pre-construction activities and the opportunities this presented for process improvement. Process benchmarking was adopted rather than performance benchmarking because it was considered that this would result in more accurate information. The benchmarking methodology developed included the establishment of several important parameters. Six partner councils with similar populations and infrastructure requirements were identified for participation in the scheme and although this showed that few of the councils participating were fully aware of their own processes in the initial stages, ultimately it led to useful understanding of preconstruction processes and identified opportunities for improvement.

The paper by Kellick (2010) covers another area of interest highlighted by IFME. In the Australian city of Joondaloop the first stage of a comprehensive asset management plan was developed in 2000, ultimately resulting in the establishment of an asset management business unit in 2006. Whilst it was determined that roads were generally in good condition, this did not apply to the city's building portfolio, including the aspect of property management. Senior management support and commitment was acknowledged as being vital for the success of the project and one of the interesting decisions taken involved the separation of operational and strategic responsibilities. 
Road safety is a common area of interest and concern and the paper by Deller (2010) explores how this problem is being addressed in Moreton Bay, Queensland. The road accident figures throughout Queensland were deemed unacceptable, and in recognition of this, a new approach was adopted to deal with road safety which focussed on gathering together input from interested groups of stakeholders rather than concentrating on engineering solutions or enforcement. This approach led to the preparation of a road safety and action plan that would take account of the obvious but sometimes forgotten fact that all road users make mistakes and that no road user should be subjected to an energy exchange so severe that it results in death or permanent injury. The plan aimed to reduce road trauma and associated costs for the community.

Continuing the subject of road safety, the next paper (Riley, 2010) examines the way in which the costs resulting from road crashes are currently identified and suggests that improvements could usefully be made to the existing classification of crashes as death, serious injury and injury crashes. Rather than relying solely on police information about accidents, the author raises the possibility of utilising data from the ambulance service records which would provide not only accurate location information but also records of injuries and severity. The author suggests that combining this with hospital data would provide much useful information for targeting limited cash resources towards the most deserving sites.

The paper by Odhiambo (2010) examines the problems associated with research into the water sector carried out by north-south partnerships, with particular reference to the African situation. The author notes that this form of collaborative research follows the course of action adopted at the United Nations 1979 conference on science and technology but outlines the many issues tending to undermine the success of these partnerships - including contrasting perceptions of researchers from northern and southern backgrounds - and how these may adversely affect the outcome. The paper concludes that north-south partnerships on their own are not sufficient to produce satisfactory outcomes and that further research is required into how these are conducted to improve their efficiency.

Drinking water is the topic of the next paper (van Heck, 2010) which summarises the service performed by Waternet, the first water cycle company in the Netherlands to be involved in managing groundwater and surface water, wastewater collection and treatment, and drinking water abstraction, production and distribution in Amsterdam and its surroundings. The author discusses experience gained in these matters from other countries, including the UK. The various steps in the process are described, along with aims and objectives of how the desired long-term level of service can be achieved and an outline of possible future steps which could be adopted to meet the various challenges which lie ahead.

'Flooding and the role of the local authority' is the theme of the final paper (McRobert, 2010) which deals with several aspects of this problem including frequency of occurrence, damage caused and relevant legislation. Attention is drawn to various reasons for the increased risk of flooding, highlighting the growth of built up areas and the tendency for the conversion of former floodplains into areas of housing, industrial development and so on, all of which contribute to an increased amount of run-off. The main provisions of the 1961 and 1997 Scottish flooding legislation acts are summarised along with reference to the latest legislation introduced in 2009 which requires more cooperation between other stakeholders. Finally, the arguments for and against the view that climate change is directly responsible for any increase in the frequency and intensity of flooding are examined.

\section{REFERENCES}

Deller J (2010) Road safety community partnership in Queensland, Australia. Proceedings of the Institution of Civil Engineers, Municipal Engineer 163(4): 225-232, doi: 10.1680/muen.2010.163.4.225.

Glencross-Grant R (2010) Developments in engineering education for rural Australia. Proceedings of the Institution of Civil Engineers, Municipal Engineer 163(4): 209-213, doi: 10.1680/muen.2010.163.4.209.

Hawley P, O'Rourke S and Bailey I (2010) Process benchmarking in Dubbo City Council, Australia. Proceedings of the Institution of Civil Engineers, Municipal Engineer 163(4): 215-220, doi: 10.1680/muen.2010.163.4.215.

Jenkinson I (2010) Developing best practice: the role of the professional journal. Proceedings of the Institution of Civil Engineers, Municipal Engineer 163(4): 205-208, doi: 10.1680/muen.2010.163.4.205.

Kellick P (2010) Developing a strategic asset management framework. Proceedings of the Institution of Civil Engineers, Municipal Engineer 163(4): 221-224, doi: 10.1680/ muen.2010.163.4.221.

McRobert J (2010) Flooding and the role of the local authority. Proceedings of the Institution of Civil Engineers, Municipal Engineer 163(4): 257-262, doi: 10.1680/ muen.2010.163.4.257.

Odhiambo F (2010) Do partnerships produce relevant knowledge in water research. Proceedings of the Institution of Civil Engineers, Municipal Engineer 163(4): 239-245, doi: 10.1680/muen.2010.163.4.239.

Riley PJ (2010) Assessing the cost of vehicle crash injuries to the community. Proceedings of the Institution of Civil Engineers, Municipal Engineer 163(4): 233-237, doi: 10.1680/ muen.2010.163.4.233.

van Heck GJ (2010) Waternet drinking water tactical planning process. Proceedings of the Institution of Civil Engineers, Municipal Engineer 163(4): 247-256, doi: 10.1680/muen.2010.163.4.247.

Vaskelainen J (2010) Briefing: IFME representing municipal engineering. Proceedings of the Institution of Civil Engineers, Municipal Engineer 163(4): 203-204, doi: 10.1680/ muen.2010.163.4.203. 